\title{
NÁLEZ MOBILNÍHO PENĚZOKAZECKÉHO VYBAVENÍ NA HRADĚ ŽAMPACH (OKRES ÚSTÍ NAD ORLICÍ)
}

\author{
MIROSLAVA CEJPOVÁ - MARTIN HLOŽEK
}

\begin{abstract}
Abstrakt: Předběžná studie je věnována popisu terénni situace, okolnostem a historické souvislosti spojené s nálezem mobilního vybavení penězokazecké dílny na hradě Žampach ve východních Čechách. Mince falšoval kovár̆ Jan se svými spolupracovniky mezi lety 1536 a 1539, v době, kdy byl hrad vástavě, nevyuživaný a zpustlý. Při záchranném archeologickém výzkumu byly objeveny zlomky technické keramiky, kovové plíšky a struska. Technická keramika a plišky byly podrobeny předběžným rozborům pomocí ručního rentgen-fluorescenčního spektrometru a elektronového mikroskopu s energiově-disperzním analyzátorem.
\end{abstract}

Klíčová slova: penězokazectví-technická keramika - hrady-chemické analýzy - XRF-SEM-EDX.

\section{The Find of Mobile Counterfeiting Equipment at Žampach Castle (Ústí nad Orlicí District)}

Abstract: This study describes the context, circumstances and historical connections of the find of a mobile counterfeiting workshop at Žampach Castle, eastern Bohemia. Coins were counterfeited by blacksmith Jan and his collaborators in 1536-1539 when the castle was forfeited, out of use and deserted. Rescue archaeological research uncovered fragments of technical ceramics, metal plates and slag. The technical ceramics and metal plates were analyzed by a manual X-ray fluorescence (XRF) spectrometer and an electron microscope with energy-dispersive analysis.

Key words: counterfeiting - technical ceramics - castles - chemical analyses - XRF - SEM-EDX.

\section{Úvod}

Pomocí rentgenově fluorescenčního spektrometru (XRF) a elektronového mikroskopu s energiově-disperzním analyzátorem (SEM-EDX) byly zkoumány vzorky dokládající činnost falzátorské dílny získané při archeologickém výzkumu středověkého hradu Žampach (okr. Ústí nad Orlicí, ČR). Na této lokalitě shledáváme zcela unikátní situaci: Fungování dílny nám dokládají písemné prameny, dále archeologické nálezy technické keramiky a odpadu v podobě strusek nebo plíšků. Naopak sama falza nebo plechy s negativy po vystřižených střížcích, které jsou hlavním dokladem falšování mincí na ostatních lokalitách, nám zde prozatím úplně chybí. $\mathrm{V}$ rámci této studie se pomocí analytických metod pokusíme naznačit cestu $\mathrm{k}$ získání indicií, které by naše předpoklady spolehlivěji doložily. Předložený text není bohužel úplným výstupem, resp. popisem zpracování archeologického materiálu a chemických analýz veškerých nálezů souvisejících s činností padělatelské dílny na hradě. Podrobné zpracování materiálu by bylo možné pouze za podpory grantového projektu.

\section{Poloha, historie a archeologický výzkum hradu}

Hrad Žampach (k. ú. Žampach, okr. Ústí nad Orlicí, Pardubický kraj, nemovitá kulturní památka r. č. 46193/6-4168) byl postaven při kolonizaci podhůří Orlických hor. Jeho zakladatelem byl někdo z př́slušníků rodu, který zpočátku využíval přídomku „ze Zebína“ (pravděpodobně hrad Hlavačov u Chocně) a v erbu měl loveckou trubku. Tento rod se podílel na organizaci osídlování Žampašska a po vystavění Žampachu se již psal po tomto hradu (Musil 2002, 167). První nepřímá zmínka o existenci hradu je ve Zbraslavské kronice. K roku 1308 je zde popisováno pustošení klášterního majetku u Lanškrouna, Ústí nad Orlicí a Třebové Ješkem řečeným ze Šildberka, Janem Vusthubem, Petrem ze Žampachu (v latinském originále psáno Petr de Sandbach), Jenišem ze Supí Hory (z Kyšperka), Bohuňkem ze Šumberka, Vítkem ze Švábenic a Oldřichem z Brandýsa, vesměs sousedy východočeského majetku kláštera. Klášter si musel pokoj pro tento svůj majetek vykoupit částkou 300 hřiven (stříbra), z nichž Petr ze Žampachu obdržel šedesát (Žitavský 1976, 218-219). Podle tohoto i dalších pramenů zněl původní německý název hradu 
Sandbach, tj. „písčitý potok“, z něho pak vznik1 český název Žampach (Profous-Svoboda 1957, 803-804).

Někdy mezi lety 1312 (Sedláček 1883, 125) a 1324 se Žampach neznámým způsobem dostal do držení královské komory a Jan Lucemburský roku 1324 postoupil Žampach s př́íslušenstvím jako léno Jindřichovi mladšímu z Lipé. Po roce 1346 hrad získal od pánů z Lipé opět jako královské léno Jan ze Smojna řečený Pancíř, který hrad využil jako základnu pro loupeživé výjezdy do okolí. Pravděpodobně roku 1356 proti němu vytáhlo královské vojsko pod vedením Karla IV. Hrad byl dobyt a Pancír pověšen (Musil 2002, 168-169). Majetek Jana ze Smojna připadl králi, který ho na př́ímluvu nejvyššího maršálka Čeňka z Lipé a Beneše z Vartemberka daroval Čeňkovi z Potštejna, jenž se stal praotcem pánů Žampachů z Potštejna. Darovací list byl napsán 28. 8. 1367, k vlastnímu daru však došlo dříve, protože Čeněk držel panství již roku 1361 (Sedláček 1883, 125). F. Musil uvádí jako datum postoupení Žampašska rok 1357 (Musil 2002, 169). V držení pánů ze Žampachu byl hrad až do poloviny 16. století, kromě let 1427-1429, kdy ho držel Jan Městecký z Opočna.

Ve druhé polovině 15 . století došlo pravděpodobně ke stavebním úpravám hradu nebo k jeho přsstavbě. Určitě došlo k úpravám paláce. Dokladem je zpráva zachovaná u Karla Bienenberka o kameni na jihovýchodním nároži hradního paláce, na němž četl Bienenberk letopočet 1469. Snad i v souvislosti s těmito stavebními aktivitami se pánové ze Žampachu dostali do finančních obtíží. Desátého října 1513 zastavil Jan ze Žampachu pro velké dluhy hrad Žampach s dalším zbožím Burjanovi Trčkovi z Lípy a na Lipnici za 3288 kop grošů s tím, že kdyby on nebo jeho dědici hrad vyplatili, bude jim vrácen i se všemi svršky a nábytkem, a pokud by se na majetku stala nějaká škoda, bude zástavním držitelem nahrazena. Zboží však nezůstalo v rukou jednoho zástavního držitele. Burjan Trčka z Lípy postoupil svá práva k Žampachu roku 1519 Haimanovi Krušinovi z Lichtemburka, Haiman 28. května 1521 Vojtěchovi z Pernštejna. Zástavní držitelé hrad neudržovali, a to ani páni z Potštejna, kteří panství spojili s panstvím Litickým. Hrad vyplatil až Zdeněk ze Žampachu, kterému hrad připadl, když si synové Jana z Potštejna na Žampachu 12. ledna 1539 rozdělili dědictví po otci.

Celé zboží bylo v tak špatném stavu, že si Zdeněk ze Žampachu pozval komorníka desek zemských Václava ze Šonova, aby provedl ohledání. Popis zpustlého hradu Chudoba a předhradí vlastního hradu Žampach se tak zachoval v deskách zemských. Zdeněk ze Žampachu se snažil získat náhradu za vzniklou škodu soudním sporem s Janem z Pernštejna, který přebral majetek jako dědictví po svém bratrovi Vojtěchovi roku 1534. Soudní pře se táhla až do roku 1547, kdy vypršely lhůty a spor byl ukončen, aniž Zdeněk něčeho dosáhl. Zdeněk ze Žampachu zemřel roku 1560 nebo 1562. Jeho synové prodali „Zámek Žampach s hradem při něm Chudobou, s dvorem poplužním s poplužím pod zámkem Žampachem" roku 1574 Janovi staršímu ze Žerotína na Náměšti a Adamovi Bukovskému z Hustířan, kteří se mezi sebou podělili tak, že Žampach zůstal ve vlastnictví Adama Bukovského. Jeho syn Otík Bukovský celé zboží prodal roku 1626 Fridrichovi staršímu z Oprštorfu, Dubu a Frydštejna na Přestavlcích. Výslovně se uvádí zámek Žampach s hradem při něm Chudobou (Chudoba ani Žampach nejsou uváděny jako pusté), se dvorem pod týmž zámkem. Fridrich zemřel bezdětný roku 1630, všechno své zboží odkázal řádu tovaryšstva Ježíšova. Majetek připadl nově založené hradecké koleji, v jejímž držení byl až do zrušení řádu.

Během třicetileté války byl hrad i dvůr pod ním několikrát napaden, vydrancován a od druhé poloviny 17. století už je hrad uváděn jako pustý. Zůstala zde funkční pouze hradní kaple sv. Kř́iže, kterou nechal roku 1672 hradecký rektor Tobiáš Reichel opravit kamenem získaným ze zdiva opuštěného hradu. Ve druhé polovině 17. století bylo kamene z hradu použito i při výstavbě nové jezuitské rezidence, jejíž součástí se stala i kaple sv. Bartoloměje. Kaple na hradě od té doby chátrala, po zrušení ŕádu byla roku 1787 prodána a nový majitel ji zbořil. Na konci 18. století stály ještě na Žampachu vysoké zdi, při jejichž bourání přišel o život jeden z dělníků (Sedláček 1883, 125-131). Po zrušení řádu v roce 1773 přešlo panství do rukou státního Náboženského fondu. Dalšími majiteli byli převážně zbohatlí měštané. V roce 1806 ho koupil plátenický handlír Gottfried Rosche von Schönlinde, v roce 1817 jeho švagr František Wünsch, jehož dědicové 
Ernst a Anna Wünschovi ho prodali roku 1822 Vácslavu Novákovi. Majetek držel od roku 1823 jeho vnuk Jan Novák. Zadlužený statek koupil 13. února roku 1841 Jan David von Stark. Po dědickém vypořádání po Janu Davidovi koupil majetek 16. června 1859 kníže Alfons Chimay, od jeho dědiců pak roku 1869 Jiří Parisch. Poté se rychle po sobě vystřídali roku 1870 Jindřich Küstner, 1871 Heliodor Heindl, ještě téhož roku František Chleborád, roku 1872 Dr. Edvard Eiselt a František, rytír von Hopfen. V roce 1884 koupila zámek Anna Gustava z Lützovů, manželka Františka Lützova, rakouského diplomata. Manželé Lützovovi nechali na konci 19. století upravit hradní areál. Byla zde postavena dnes již zaniklá dřevěná rozhledna a lávka spojující předhradí a vlastní hrad a byla provedena konzervace zbytků zdiva. Po smrti Anny Gustavy Lützovové zdědila zámek v roce 1933 Henrieta Campo-Franco, roku 1945 byl zámek konfiskován (Adamec 2006, 10-12). V současné době je hrad v majetku Lesů ČR, s. p.

$\mathrm{V}$ první polovině 16 . století, v době, kdy byl hrad v zástavě, zde nějakou dobu pracovala penězokazecká dílna. Informace o její činnosti, dopadení, odsouzení a potrestání jejích provozovatelů jsou zaznamenány v nejstarší dochované pardubické smolné knize, nejpodrobněji je zpracoval a publikoval F. Šebek (2010, 285-297). Podmínky pro činnost falzifikátorů vznikly $\mathrm{v}$ době, kdy bylo žampašské panství zastaveno a dostalo se do majetku pánů z Pernštejna, kteří ho spojili s panstvím litickým a hrad nevyužívali. Toho využil žampašský kovář Jan, který se, zřejmě s vědomím vrchnostenských úředníků, na Žampachu usadil i se svou ženou a čeledí. V hradním sklepení spolu s Janem Smolíkem falšoval zhořelecký černý peníz, vídeňský peníz zvaný „rohatý“ - patrně půlkrejcar v hodnotě tříhaléře, a rakouský groš - trríkrejcar (Šebek 2010, 285-297). Později se k nim přidali ještě Jan Krška, který se kromě distribuce podílel i na ražbě mincí („,A já těch peněz sem odbýval a roznášel, i také sem jich pomáhal dělati, i fermež sem na ně dával a dělal orlický penize a rakouské groše po 6 denárech a vídeňský penize po třech haliřrich"), a krčmář Jiří Vodička z nedaleké Hnátnice, který dle Kršky peníze rozvážel a dodával materiál („A plechy $k$ tomu a méd’ jednával nám Jiřik Vodička, krčmár̆, kterej v ten čas byl v Hnátnici a nyníčky na Plesu jest krčmářem proti kostelu u tvrze“). Na činnost dílny se přišlo náhodou. V červnu 1542 byli v Chlumci nad Cidlinou nebo na chlumeckém panství zadrženi a obratem v Chlumci na mučidlech vyslechnuti dva podezřelí muži. Jeden z nich byl Jan Krška, který při výslechu popsal činnost žampašské dílny i distribuci falešných peněz. To vedlo k zatčení a výslechům kováře Jana a krčmáře Jiřího Vodičky. Čtvrtý výtečník, Jan Smolík, zahynul násilnou smrtí ještě před odhalením celé skupiny. Výpovědi kováře Jana, Jana Kršky i Jiřího Vodičky zveřejnil J. Francek (2011, 169-174). Podle Jana Kršky si razidla na mince zhotovil kovář sám, což ukazuje na to, že ovládal základy zlatnického (šperkařského) řemesla („Kolky k dělání k těm penězům, ty jest sobě sám dělal ten kovářr, neb jest velmi mistrnej a vtipnej a literát dobrej"). Na postříbření používali jáchymovské tolary a staré groše (Krška vypověděl: „Když byl ptán, kde sou stř́bro brali k těm penězům, pověděl, že jest tu stř́bra netřeba mnoho, než když přepustili jochmtál nebo dva a mezi to některý groš starý, tehdy sme jich nemálo nadělali.“). Podle výpovědi kováře Jana zajišt’ovali distribuci Krška, Vodička i Smolík („Item též vyznal, což sou těch peněz víc dělali, že sou je roznášeli Jan Krška, Jiřik Vodička a Jan Smolik, pravic, že do Uher a jinam, kdežkkoli věděli."). Kovář Jan prodával mince v bezprostř́edním okolí Žampachu, na trzích ve Slezsku, především ve Vratislavi, jimi platilo několik řemeslníků ze Žamberka a Dobrušky. Do Slezska zajížděl s falešnými mincemi i Jiří Vodička. Jan Krška rozvážel falza do oblasti jihovýchodně od Žampachu (uváděl např. Přibyslav, Humpolec, Pelhřimov, Hořepník, Chřenovice), zajížděl i na Moravu, na Slovensko a do Rakouska. Padělanou měnou platili sami, především ji však, a to i opakovaně, nejčastěji v kurzu 2:1, prodávali svým odběratelům (Francek 2011, 169-174). Ti pouštěli falza do oběhu na trzích nebo na větších shro-

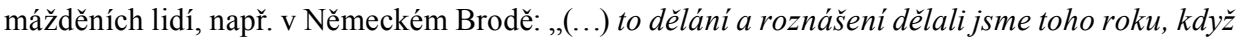
to taženi bylo, když pan Rašín táhl na vojnu a k popisu se sjel do Německýho Brodu. “Krška zde hovořil o shromáždění vojska před tažením do Uher proti Turkům v květnu 1537, kterému velel podkomoří královských věnných měst Petr Rašín z Riesenburka. Mince razil kovář se svými spolupracovníky nárazově, podle toho, jak se jim podařilo sehnat materiál, tedy měd'. Používali především kotle. Řadu z nich dodal Vodička, další získávali i krádežemi (Šebek 2010, 285-297). 
Využili také vybavení hradu. Ve zprávě Václava ze Šonova se uvádí, že v hradní kapli zmizel měděný kotel z křtitelnice a v oknech bylo jen málo skel nebo žádná (Sedláček 1883, 120-122). Padělatelská dílna fungovala zhruba v letech 1536 až 1539, minimálně od května 1537 (v květnu již prodával Krška padělky drábům v Německém Brodě) do roku 1538, její činnost skončila patrně v souvislosti s vyplacením hradu, ke kterému došlo v roce 1539. Kovář Jan, Jan Krška a Jan Vodička byli odsouzení k trestu smrti upálením (Šebek 2010, 285-297).

Hrad Žampach leží na protáhlé erozní vyvýšenině vystupující ca $100 \mathrm{~m}$ (na jihu) až $120 \mathrm{~m}$ (na severu) nad okolní terén. Na vrcholu kopce, především na jeho východním konci v prostoru hradního jádra, vystupují skalní bloky s téměř kolmými stěnami, které stavitelé hradu využili. Př́istupová komunikace esovitě stoupá po mírnější jižní straně vyvýšeniny až pod hradní jádro, kde se obrací doleva a vede příchozího obráceného nechráněnou pravou stranou $\mathrm{k}$ hradbě podél celé jižní strany hradu až k bráně, která se nacházela v úzkém čele předhradí (obr. 1). Za branou prochází předhradím podél valovitých útvarů jen s malými úseky zdiva, které v sobě skrývají relikty obvodové hradby, samotížného mlýna, Bílé věže, pivovaru a cisterny později přeměněné na pivovarskou lednici. Hradní jádro bylo oddělené od předhradí ve skále vytesaným, na obou koncích pravděpodobně zdí uzavřeným př́íkopem. V jeho severozápadní části se nacházejí relikty valeně zaklenutého zřejmě vstupního objektu, východní část zabírá torzo hradního paláce. Na severní straně, ale až pod dnešní pochozí úrovní, se na boční straně hradu dochovaly velké úseky obvodové hradby včetně mohutného opěráku. Hradba tam obezdívala horní části skalních bloků a uzavírala mezery mezi nimi, její základová spára proto není skrytá v zemi, naopak leží přímo na skále. Kromě zajištění nepřístupnosti tato úprava rozšiřovala extrémně úzký prostor horního hradu.

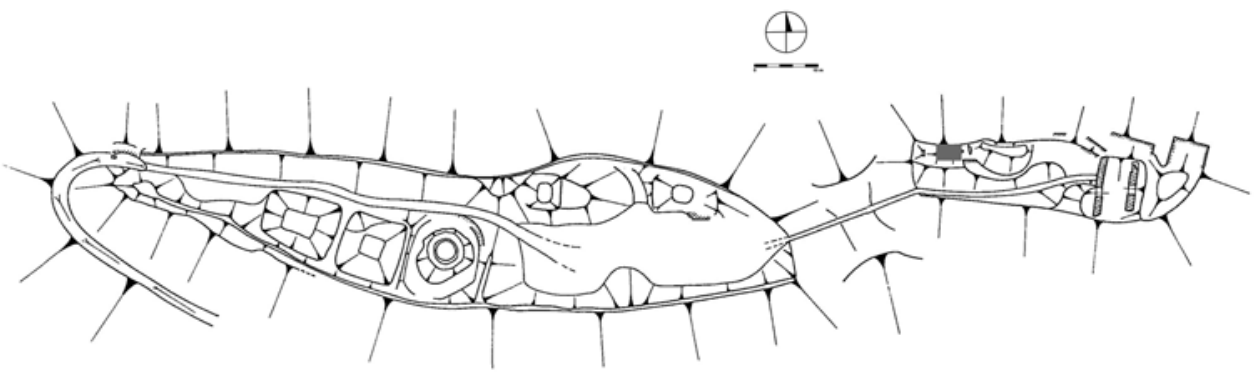

Obr. 1. Hrad Žampach, okr. Ústí nad Orlicí. Plán hradu se zakreslením sondy E. Zaměření M. Cejpová, P. Cejp. Abb. 1. Burg Sandbach, Bezirk Ústí nad Orlicí. Planskizze von Burg Sandbach mit eingezeichnetem Sondierschnitt E. Vermessung M. Cejpová, P. Cejp.

Vstupní objekt je z větší části pod povrchem terénu, klenba tvoří mírnou vyvýšeninu překrytou destrukčními vrstvami a drnem, zaklenutí je vidět pouze na východní a západní straně v místě, kde je budova zřícená. Prostor pod klenbou byl před opravou z větší části vyplněný splachy a humózní vrstvou. Blíže východního konce dochované části stavby se klenba neznámo kdy prolomila, vznikl otvor o velikosti ca $2 \times 1 \mathrm{~m}$. Ve vzniklém otvoru bylo zdivo viditelné na severní, východní a západní straně, na jihu, kde klenba nasedala na jižní obvodovou zed’ budovy, zdivo pozorovatelné nebylo. V prostoru pod klenbou se v tomto místě nenacházela žádná sutová destrukční vrstva, proto je možné předpokládat, že jde o staré narušení. Jeho zajištění bylo provedeno $\mathrm{v}$ roce 1991, kdy byly na hradě zahájeny zajištovací a rekonstrukční práce. Vzhledem k tomu, že se tehdy pozornost soustředila především na hradní palác a opěrák v obvodové hradbě, byla po dohodě s pracovníky organizace památkové péče provedena pouze provizorní oprava zasypáním otvoru materiálem získaným při dalších terénních úpravách.

V roce 2013 přistoupil majitel hradu, Lesy ČR, s. p., k vybudování turistického okruhu v prostoru zříceniny hradu (p. p. č. 747/1) a v prostoru př́stupové cesty k hradu (p. p. č. 708, 713, 717, 947). Projektovou dokumentaci (Hrad Žampach, vybudování turistického okruhu v prosto- 
ru zříceniny hradu, jednostupňový projekt) zpracovala firma MURUS, spol.sr. o. Součástí prací na vytvoření turistického okruhu bylo i zajištění propadlé klenby ve vstupním objektu hradního jádra, které vyvolalo záchranný archeologický výzkum. V místě otvoru v klenbě byla položena sonda $\mathrm{E}$ o rozměrech stran $2,15 \times 3,56 \times 2,17 \times 3,76 \mathrm{~m}$, jejímž cílem bylo odhalit rub klenby v rozsahu $0,5 \mathrm{~m}$ od okraje narušení, což byl minimální odkryv nezbytný pro její doplnění. Protože se na jižní straně v místě narušení nedařilo objevit ani zbytky klenby (zed' 901), ani jižní zed' budovy (zed' 903), na kterou klenba nasedala, byla sonda směrem k jihu, východu a západu rozšířena na $2,40 \times 3,80 \times 2,60 \times 3,94 \mathrm{~m}$ (obr. 1, 6). Přesto se jižní zed' zkoumané budovy nepodařilo zachytit. Příčinou může být oproti původnímu předpokladu mnohem rozsáhlejší destrukce zdiva nádvorní zdi v tomto místě, vyloučit nelze ani to, že se zde nacházel vstup z nádvoří a klenba se zřítila tam, kde do ní byla nad vchodem vložena luneta. Vzhledem k tomu, že na rozšíření záchranného archeologického výzkumu, tak aby bylo možné ověřit tyto teorie, a na následné, oproti projektu výrazně složitější stavební práce nebyl ani čas, ani finanční prostředky, bylo na kontrolním dnu stavby rozhodnuto o změně projektu. Klenba nebyla doplňována, pouze podezděna kameny kladenými na sucho (zed' 902, obr. 5) a celý prostor narušení byl zasypán, takže místo, kde je klenba propadlá, se na povrchu terénu nijak neprojevuje.
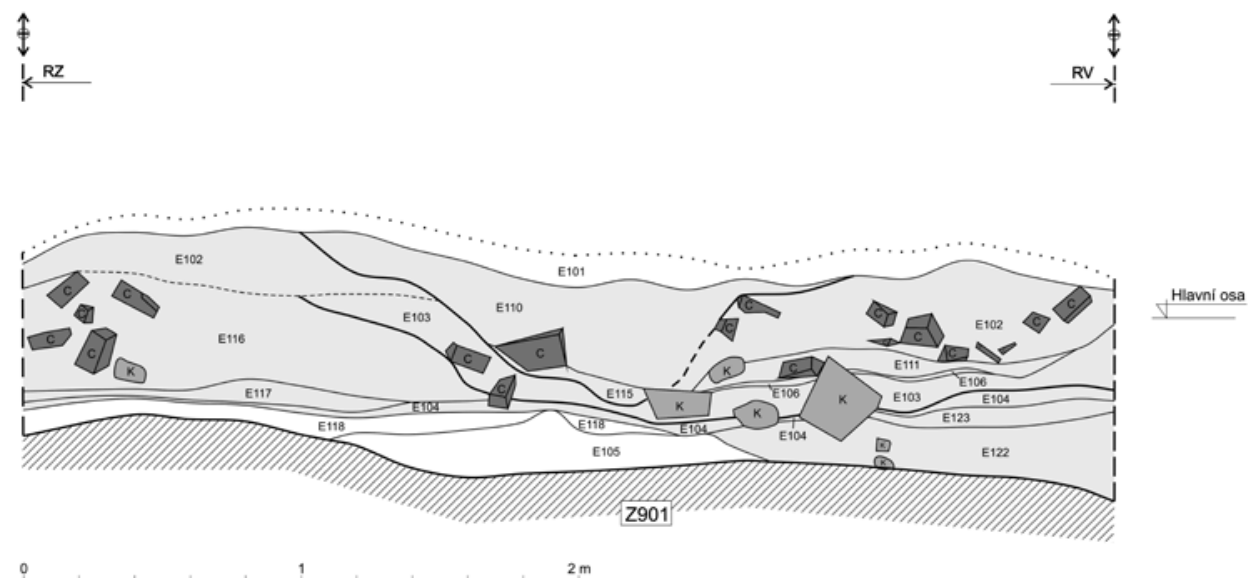

Obr. 2. Hrad Žampach, okr. Ústí nad Orlicí. Sonda E, severní řez. Světle šedá označuje uloženiny obsahujíí technickou keramiku. Zaměření a digitalizace M. Cejpová.

Abb. 2. Burg Sandbach, Bezirk Ústí nad Orlicí. Sondierschnitt E, nördlicher Schnitt. In Hellgrau sind Ablagerungen mit technischer Keramik gekennzeichnet. Vermessung und Digitalisierung M. Cejpová.

V průběhu záchranného archeologického výzkumu byly rozebrány uloženiny překrývající rub klenby kolem jejího narušení a část uloženin v prostoru pod propadlou klenbou. Nejstarší vrstvy, které je snad možné spojovat se vznikem klenby, jsou klenební zásypy, označené E 105, 118, 120 (obr. 2, 3). Ve zkoumaném prostoru nebyl odkryt styk klenby a zdi budovy, takže nebylo možné posoudit, zda je klenba původní nebo dodatečně vložená. V hradním paláci je klenba viditelně pozdější (pískovcové kvádry přitesané pro její vložení). V průběhu destrukce hradu a jeho přechodu ve zř́iceninu došlo v severovýchodní a východní části vstupního objektu k destrukci takového rozsahu, že se odhalil rub klenby a byly odplaveny i klenební zásypy. Bylo to způsobeno tím, že v prostoru mezi stávajícími relikty vstupního objektu a hradního paláce došlo ke zřícení severní obvodové hradby, která byla založena na skalních výstupech hluboko pod úrovní nádvoří. Vzniklým otvorem pak docházelo ke splavování sutových a archeologických vrstev na prudké svahy pod hradem. Odhalený rub klenby a klenební zásypy překryly destrukční vrstvy, E 104, 116, 117, 122, 123 (obr. 2, 3). Tyto destrukční vrstvy narušilo další 

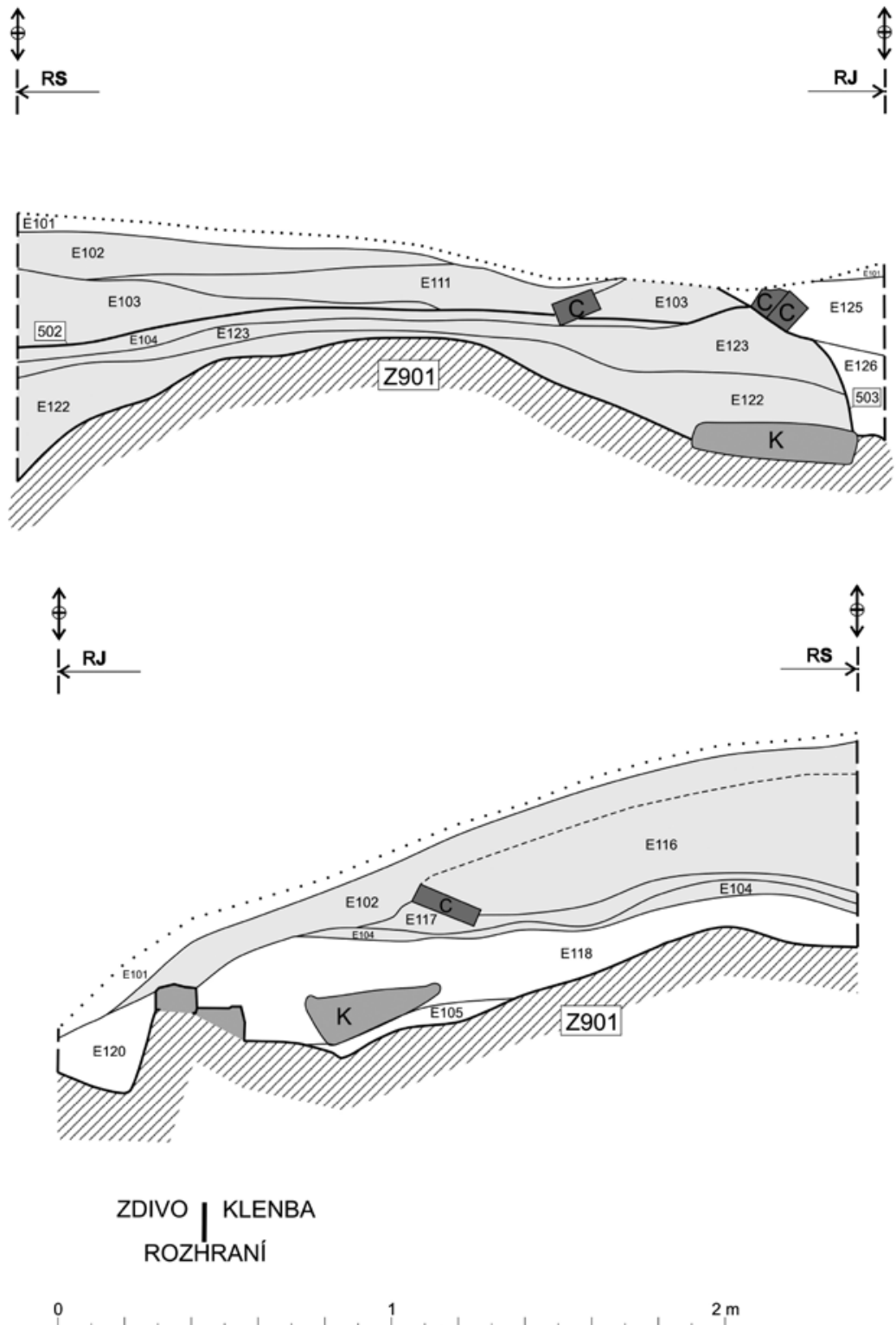

Obr. 3. Hrad Žampach, okr. Ústí nad Orlicí. Sonda E, východní a západní řez. Světle šedá označuje uloženiny obsahující technickou keramiku. Zaměření a digitalizace M. Cejpová.

Abb. 3. Burg Sandbach, Bezirk Ústí nad Orlicí. Sondierschnitt E, östlicher und westlicher Schnitt. In Hellgrau sind Ablagerungen mit technischer Keramik gekennzeichnet. Vermessung und Digitalisierung M. Cejpová.

vyplavování materiálu z hradu, vzniklý prostor (výkop 502) vyplnily uloženiny E 103, 106, 111. Výplně i vrstvy překryla další destrukční vrstva E 102 (obr. 2, 3). Nejmladší jsou erozní prohlubně 501, s výplněmi E 110, 115, a 503, s výplněmi E 109, 112A, B, 113, 119, 124, 125, 126. Vše nakonec překryla drnová vrstva, E 101, a v místě pěšiny, po které chodí návštěvníci hradu, ušlapaná, místy oderodovaná vrstva, E 127 (obr. 2-5, 7). 
Mezi běžnými nálezy se při archeologickém výzkumu objevily úlomky technické keramiky, zlomky tyglíků, prubířských misek a kelímků pokrytých uvnitř, ale často i zvenku vrstvami černého, červeného, hnědočerveného, zeleného a šedozeleného skla. Bylo zřejmé, že jde o odpad vzniklý při provozu penězokazecké dílny kováře Jana a jeho společníkủ. Na řezech (obr. 2-5) jsou světle šedou barvou vyznačené uloženiny, které tuto technickou keramiku obsahovaly. Spolu s ní byla nalezena běžná kuchyňská a stolní keramika z 15. a 16. století, struska (analýzami
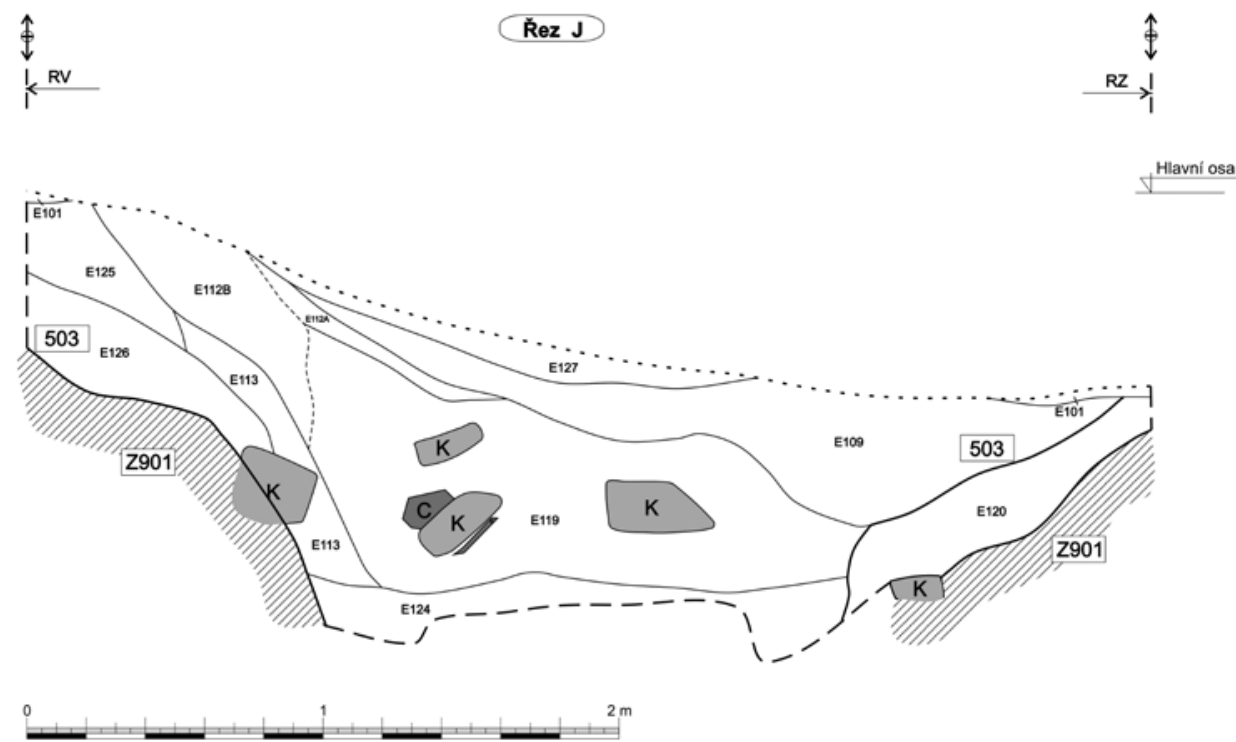

Obr. 4. Hrad Žampach, okr. Ústí nad Orlicí. Sonda E, jižní řez. Světle šedá označuje uloženiny obsahující technickou keramiku. Zaměření a digitalizace M. Cejpová.

Abb. 4. Burg Sandbach, Bezirk Ústí nad Orlicí. Sondierschnitt E, südlicher Schnitt. In Hellgrau sind Ablagerungen mit technischer Keramik gekennzeichnet. Vermessung und Digitalisierung M. Cejpová.

bylo prokázáno, že vedle běžné kovářské to byla i struska vzniklá při zpracování barevných kovů), ojediněle zlomky nádobkových a komorových kachlů (zajímavý je zlomek prořezávaného kachle s figurálním motivem). Podařilo se získat také tři drobné mince (určil F. Šebek). Ve vrstvě 122 byl objeven jednostranný peníz se lvem a čtyřrázem Václava IV., ražený od roku 1384 do začátku 20. let 15. století. Jednostranný bílý peníz Vladislava Jagellonského (1471-1516), ražený v Kutné Hoře, byl ve vrstvě 104, vídeňský fenik se čtyřrázem, ražba po roce 1426, se nacházel na rozhraní vrstev E 102 a E 116. Vedle technické keramiky se podařilo získat i několik úlomků barevných kovů, z nich nejvýznamnější byly čtyři drobné ústř̌žky plechů nalezené ve vrstvách E 104 a E 123. Bohužel se nepodařilo objevit ani jedno falzum. Malé množství kovových nálezů je možné přičíst tomu, že kováři bylo známo, že se hrad bude vracet původním majitelům, a proto se snažil odstranit všechny stopy svého mincování, dobře věděl, že se ražba falešných mincí trestá upálením. Technická keramika má krátkou dobu použitelnosti, např́íklad množství prubiřrských misek objevených v Kutné Hoře naznačuje, že byly používány pouze jednorázově a pak se vyhazovaly (Bartoš-Brzák-Ševců 2000, 47). Za několik let provádění, byt' jen občasných ražeb, se tak jistě snadno nashromáždilo množství vyhozených střepů i další podobné keramiky smíchané s ostatním odpadem, který na hradě zůstal. Technická keramika i plíšky byly $\mathrm{v}$ kontextech společně $\mathrm{s}$ keramikou datovanou do širokého časového rozpětí a s mincemi, $\mathrm{z}$ nichž jen dvě mohly být $\mathrm{v}$ oběhu v době fungování penězokazecké dílny (vídeňský fenik se čtyřrázem ražený po roce 1426 se jen sotva používal o ca 100 let později). To i vlastní charakter vrstev jasně ukazuje na to, že nejde o nálezy in situ, a zkoumané konstrukce tak nemůžeme přímo spojit s vlastní dílnou. Otázkou tedy zůstává její umístění na hradě. $Z$ výpovědi jednoho ze 
spolupracovníků kováře Jana, Jana Kršky, víme, že mince kovář dělal v hradním sklepení (Šebek 2010, 287). Termínem sklepení se tehdy označovala klenutá místnost, vzhledem k provozu, který v ní probíhal, je velice pravděpodobné, že musela být vybavená komínem. Takový prostor se ve zřícenině hradu nedochoval a je jen malá pravděpodobnost, že by mohl být skrytý pod úrovní terénu. Starší archeologické výzkumy v hradním jádře Žampachu probíhaly v souvislosti

$$
\text { k RZ } \quad \text { RV }
$$

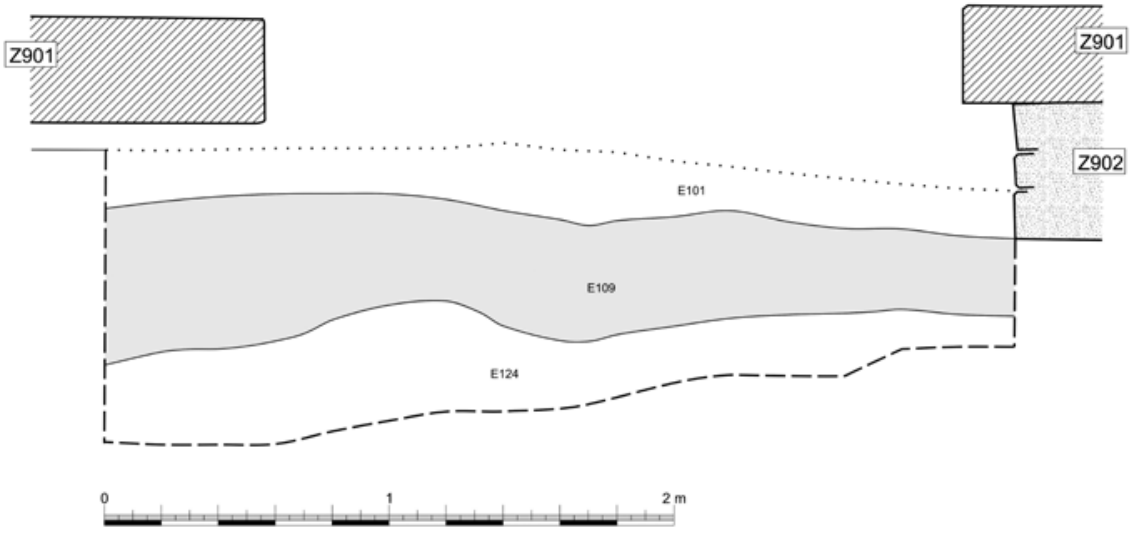

Obr. 5. Hrad Žampach, okr. Ústí nad Orlicí. Sonda E, pomocný řez. Světle šedá označuje uloženiny obsahující technickou keramiku. Zaměření a digitalizace M. Cejpová.

Abb. 5. Burg Sandbach, Bezirk Ústí nad Orlicí. Sondierschnitt E, Hilfsschnitt. In Hellgrau sind Ablagerungen mit technischer Keramik gekennzeichnet. Vermessung und Digitalisierung M. Cejpová.

s opravami hradu v prostoru opěráku a reliktu hradního paláce. V destrukčních vrstvách nad klenbou př́izemí palácové budovy se nalezl tyglík, který dle analýzy na svém vnitřním povrchu prokazatelně obsahoval částice slitiny stříbra a zlata (Ventura 2005). Žádná další technická keramika objevena nebyla. I když rozsah archeologického výzkumu v prostoru hradního jádra není velký, výrazná koncentrace technické keramiky v sondě E oproti jedinému nálezu v západní části hradního jádra umožňuje vyslovit předpoklad, že se dílna nacházela v západní části hradního jádra ve vstupní budově.

Penězokazecké dílny nacházíme i na dalších hradech. Nejlépe dochovaná byla dílna z doby kolem roku 1440 na hradě Skály (Belcredi 2012, 583-598), z níž vedle unikátního nálezu výhně pochází i množství střížků a falz samých. Technická keramika však nalezena nebyla. ${ }^{1}$ Po polovině 15. století fungovala dílna na hradě Kř́́dlo u Chomýše (Kohoutek 1995, 48). Ve druhé polovině 15. století působili penězokazci i v jižním křídle hradu Špilberk, kde byly v požárové vrstvě z doby po polovině 15 . století objeveny zbytky plechu, ze kterých byly vybíjeny či vystříhávány mincovní stř́žžky, jež pak sloužily jako polotovary pro ražení pražských grošů a parvủ. ${ }^{2}$ Pod ochranou majitele hradu Gabriela Drugetha z Humenného falšoval mince na hradě Jasenov

1 Písemné sdělení PhDr. L. Belcrediho.

2 Byla na Špilberku penězokazecká díla? [on-line]. Dostupné z: http://www.spilberk.cz/byla-na-spilberku-penezokazecka-dilna/, cit. 4. 5. 2015; Archeologové: na Špilberku se padělaly mince [on-line]. Dostupné z: http://www.ibrno.cz/historie/49541-archeologicky-objev-na-spilberku-sepadelaly-mince.html, cit. 4. 5. 2015. 
(okr. Humenné, Slovenská republika) mistr Mikuláš v polovině 16. století (Plaček-Bóna 2007, 144). Bohužel v dostupných materiálech nejsou uváděny nálezy technické keramiky.

\section{Výsledky chemických analýz technické keramiky a dalších nálezů}

Chemickým analýzám bylo podrobeno několik desítek kusů technické keramiky, strusek a tři středověké mince objevené při archeologických výzkumech hradu Žampach. V níže uvedených tabulkách uvádíme pouze výběr nejzajímavějších výsledků, které především dokládají manipulaci se stř́ibrem a rtutí. Materiálové průzkumy tohoto unikátního materiálu vyžadovaly užití nedestruktivních metod, takže jako základní byla aplikována rentgen-fluorescenční analýza (XRF) pomocí ručního spektrometru Olympus DELTA INNOV-X. Analýzy byly provedeny v laboratoři Metodického centra konzervace Technického muzea v Brně. Procentuální zastoupení prvků zjištěné pomocí XRF analýz je nutné brát s jistou rezervou, údaje získané přenosnými spektrometry jsou spíše orientační. U tří exemplářů mincí a měděných plíšků byla aplikována analýza pomocí skenovacího elektronového mikroskopu s energiově-disperzním mikroanalyzátorem (SEM-EDX). Analytické práce se uskutečnily v laboratořích strukturních a fázových analýz Fakulty strojního inženýrství VUT v Brně na elektronovém mikroskopu PHILIPS XL 30. Mikroanalýzy povrchu byly provedeny na analytickém komplexu PHILIPS-EDAX. Byla užita bezstandardová analýza s dobou načíání spektra $100 \mathrm{~s}$ a urychlovacím napětím $25 \mathrm{kV}$. U každého exempláře mince a plíšku jsme provedli tři mikroanalýzy SEM-EDX na různých místech povrchu a v tabulce uvedené výsledky jsou zprůměrňované hodnoty těchto tří měření. Obdobně se postupovalo i při měření ručním XRF spektrometrem.

Rentgen-fluorescenční analýza (XRF) je nedestruktivní analytická metoda založená na buzení a detekci tzv. charakteristického záření. Emise charakteristického záření z měřeného předmětu je vyvolána dopadem záření X nebo gama $\mathrm{z}$ vhodného zdroje tohoto záření. Po dopadu

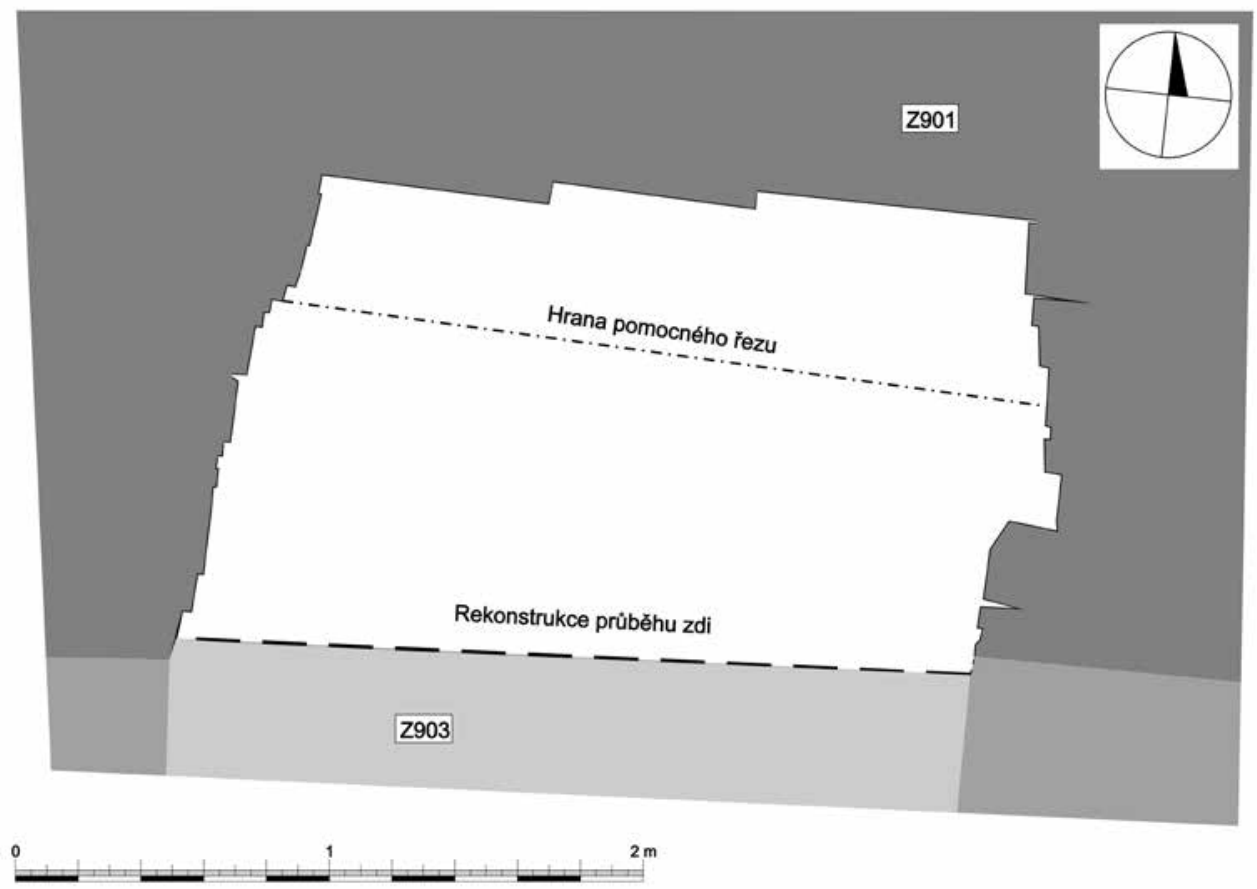

Obr. 6. Hrad Žampach, okr. Ústí nad Orlicí. Sonda E, půdorys. Zaměření a digitalizace M. Cejpová.

Abb. 6. Burg Sandbach, Bezirk Ústí nad Orlicí. Sondierschnitt E, Grundriss. Vermessung und Digitalisierung M. Cejpová. 


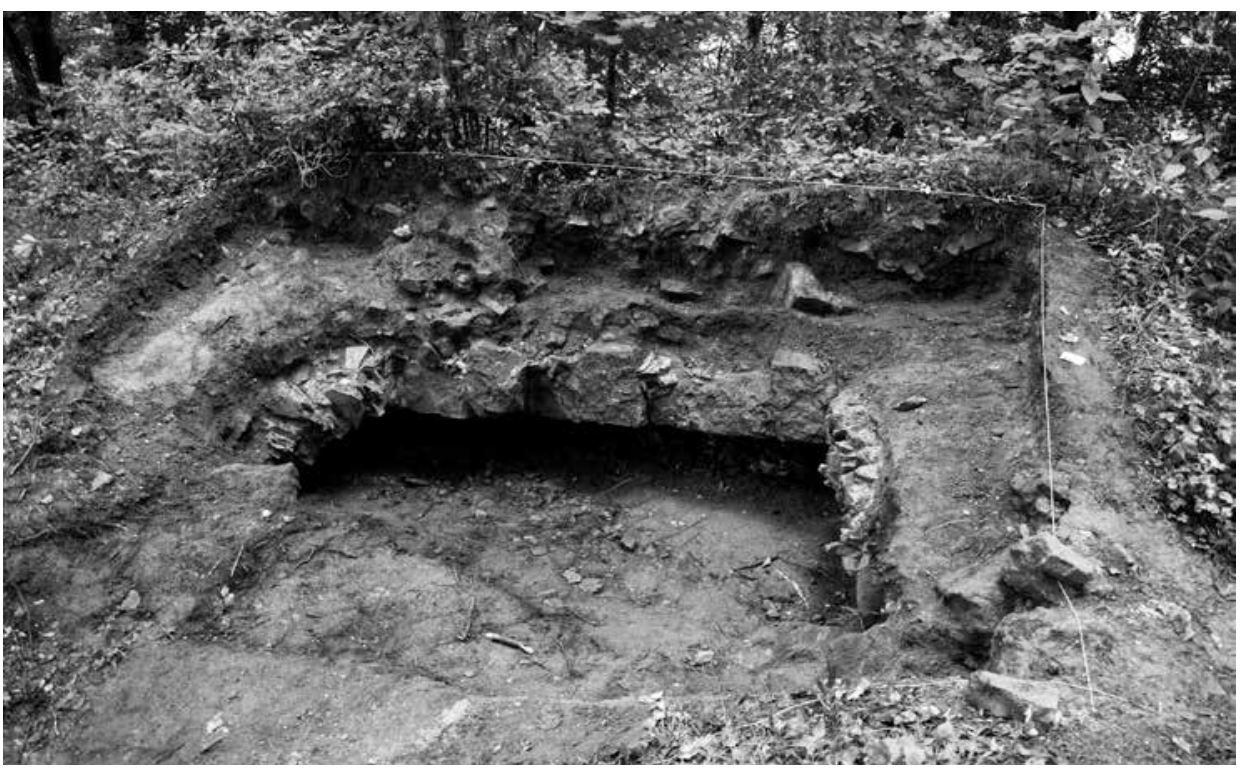

Obr. 7. Hrad Žampach, okr. Ústí nad Orlicí. Sonda E od jihu v průběhu výzkumu. Foto M. Cejpová.

Abb. 7. Burg Sandbach, Bezirk Ústí nad Orlicí. Sondierschnitt E von Süden während der Grabung. Foto M. Cejpová.

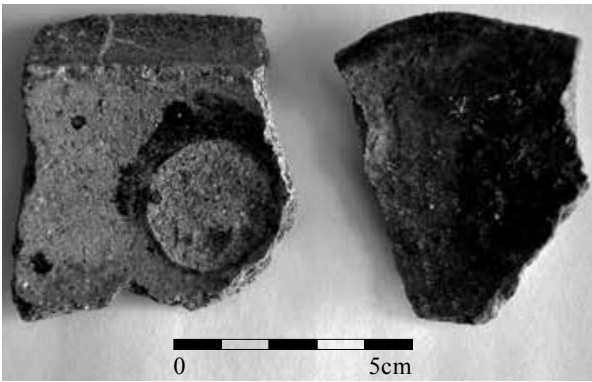

Obr. 8. Hrad Žampach, okr. Ústí nad Orlicí. Ukázka technické keramiky. Foto M. Hložek.

Abb. 8. Burg Sandbach, Bezirk Ústí nad Orlicí. Probe technischer Keramik. Foto M. Hložek.

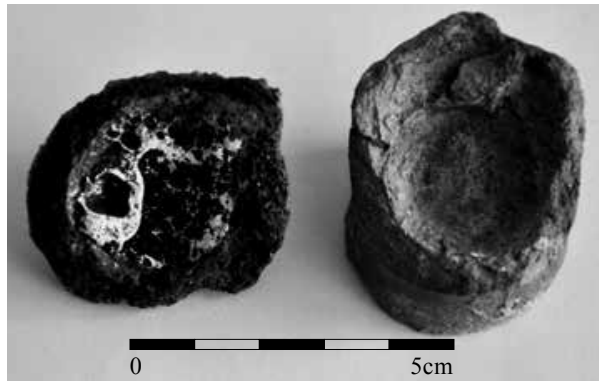

Obr. 9. Hrad Žampach, okr. Ústí nad Orlicí. Ukázka den tyglíků se stopami slévaných kovů. Foto M. Hložek.

Abb. 9. Burg Sandbach, Bezirk Ústí nad Orlicí. Proben von Schmelztiegelböden mit Gussmetallspuren. Foto M. Hložek.

záření $\mathrm{X}$ nebo gama dochází v předmětu $\mathrm{k}$ ionizaci a excitaci atomů a při následné deexcitaci se emituje záření X, nazývané charakteristické záření. Jelikož energie charakteristického záření je závislá na atomovém čísle prvku, nebot' je rovna rozdílu energií elektronových hladin v atomu daného prvku, spektrometrie charakteristického záření dovoluje identifikaci prvků a kvantifikaci jejich množství ze spekter tohoto záření naměřených spektrometrickým detektorem fotonového záření. Vývoj nových zdrojů a detektorů ionizujícího záření umožnil konstrukci přenosných aparatur, které dovolují měření mimo laboratoř. Tato multielementární analýza umožňuje identifikovat hlavní složky měřeného předmětu krátce po zahájení měření. Díky tomu lze vyvozovat některé závěry už v době analýzy a přizpůsobit tomu postup dalších měření. Při vhodně zvolené energii primárního záření mohou být identifikovány veškeré prvky s výjimkou těch $\mathrm{s}$ nízkým atomovým číslem, např. prvky organických sloučenin, nebot' emitují charakteristické zárení nízkých energií, které je významně absorbováno v měřeném předmětu, vzduchu a vstupním okénku detektoru. Běžné prŕístroje pro XRF jsou schopny dobře měřit prvky s atomovým číslem přibližně od 16 (síra) výše. Metoda XRF bývá řazena k metodám povrchové analýzy, nebot' primární 


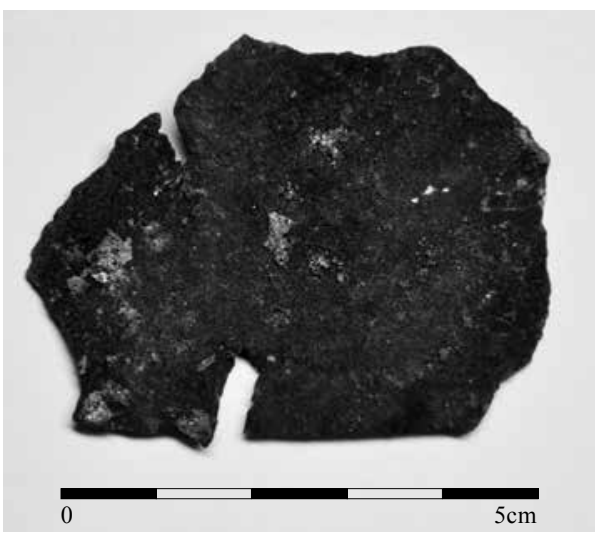

Obr. 10. Hrad Žampach, okr. Ústí nad Orlicí. Ukázka nálezu měděného plechu. Foto M. Hložek.

Abb. 10. Burg Sandbach, Bezirk Ústí nad Orlicí. Probe eines Kupferblechfundes. Foto M. Hložek. záření ze zdroje i charakteristické záření jsou $\mathrm{v}$ předmětu silně absorbovány a naměřené spektrum charakteristického záření popisuje pouze složení povrchu předmětu. Tloušt'ka analyzované povrchové vrstvy závisí na energii primárního záření a na koncentracích prvků. S výjimkou měření organických sloučenin se tloušt'ka analyzované povrchové vrstvy pohybuje $\mathrm{v}$ řádu desítek mikrometrů. V případě nehomogenního rozložení prvků platí, že čím jsou dané prvky blíže povrchu, tím více se jejich prŕítomnost projeví v naměřených spektrech charakteristického záření. To je dáno jednak nižší intenzitou primárního záření ve větších hloubkách, a jednak vyšší absorpcí charakteristického záření při výletu z měřeného předmětu. Kromě kvalitativní analýzy, jejímž cílem je identifikovat veškeré př́ítomné prvky, mohou být naměřená spektra využita i pro kvantitativní analýzu, která poskytuje informaci o koncentracích prvků nebo o tloušt'kách povrchových vrstev. Aby mohla být provedena přesná kvantitativní analýza, musí být splněno několik předpokladů. Hlavně musí být zajištěno, aby byl studovaný předmět změřen za stejných podmínek jako referenční materiál známého složení, s jehož spektrem charakteristického záření se výsledky měření porovnávají. Podmínka jednotného geometrického uspořádání experimentu vyžaduje také homogenitu a rovný povrch měřeného předmětu. Pokud nejsou tyto podmínky splněny, pak lze provést pouze tzv. semikvantitativní analýzu, při které jsou absolutní koncentrace prvků pouze odhadovány, nebo lze stanovit jen poměr koncentrací zájmových prvků. Spektra charakteristického záření nejsou téměř ovlivněna chemickou formou přítomných prvků. Z toho vyplývá, že provedená analýza neumožňuje stanovit, v jakých chemických sloučeninách se identifikované prvky v předmětu nalézají. Jen v některých případech lze z poměru hmotnostních zastoupení prvků usoudit, jaké chemické sloučeniny vytvářejí. Postup měření zaleží na vlastnostech konkrétní aparatury a zkoumaného předmětu. Nepožaduje-li se přesná kvantitativní analýza, není nutné provádět úpravu předmětu nebo vzorku před měřením. Jen v případě významné kontaminace povrchu předmětu je žádoucí tyto nečistoty odstranit, aby neovlivnily výsledek měření. Doba měření je zcela volitelná a obvykle činí několik minut. S rostoucí dobou měření klesají detekční limity pro identifikaci prvků, a zvyšuje se tedy pravděpodobnost, že budou odhaleny prvky přítomné pouze ve stopových množstvích. Díky všem uvedeným výhodám je XRF vhodná $\mathrm{k}$ měření uměleckých předmětů, archeologických nálezů a ostatních cenných objektů, které nesmí být př̀i měření jakkoliv poškozeny nebo převáženy $\mathrm{k}$ analýze do specializované laboratoře.

Skenovací elektronová mikroskopie (SEM, Scanning Electron Microscopy) je instrumentální metoda, která je zejména určena k pozorování zvětšených povrchů nejrůznějších objektů. K zobrazení předmětu metodou skenovací elektronové mikroskopie lze využít sekundární elektrony (metoda SEI, Secondary Electron Imaging), odražené elektrony (metoda BEI nebo BSE, Back Scattered Electron Imaging). Přístroj pracující s touto metodou nazýváme elektronový mikroskop. Tento př́stroj lze do jisté míry považovat za analogii světelného mikroskopu v dopadajícím světle, ale na rozdíl od něho je výsledný obraz tvořen pomocí sekundárního signálu - odražených nebo sekundárních elektronů. Díky tomuto principu je zobrazení v SEM považováno za nepřímou metodu. Velkou předností SEM v porovnání se světelným mikroskopem je jeho velká hloubka ostrosti, v důsledku které lze z dvojrozměrných fotografií ze SEM získat i jistý trojrozměrný aspekt. Další předností těchto mikroskopů je, že v komoře preparátů vzniká při interakci urychlených elektronů s hmotou vzorku kromě výše zmíněných signálů ještě i napřr. rtg záření, 
Augerovy elektrony, katodoluminiscence ad., které nesou mnoho dalších informací o vzorku. Při jejich detekci je možné určit např. prvkové složení preparátu v dané oblasti a při porovnání s vhodným standardem určit i kvantitativní zastoupení jednotlivých prvků. Energiově-disperzní mikroanalýza (EDX) využivá emise rentgenového záření, které vzniká po dopadu proudu rychlých elektronů na pevný materiál, $\mathrm{k}$ identifikaci chemického složení tohoto materiálu. Detekce rentgenového záření může být u této metody založena na energii rtg kvant (energiově-disperzní analýza). Analýza chemického složení povrchu byla provedena lokální elektronovou mikroanalýzou na stejném přístroji. Detailní analýza prvkového složení a heterogenit je také běžnou součástí měření v elektronovém mikroskopu.

\section{Popisy technické keramiky, plechů a strusek analyzovaných ručním XRF spektrometrem}

U analyzované technické keramiky byla prováděna analýza na barevně odlišných nánosech nebo skelných vrstvách tak, že XRF spektrometr byl v těchto místech přikládán přímo k povrchu vzorků. Obdobně se postupovalo u plechů z barevných kovů, kdy bylo nutné brát v úvahu, že analýza bude zahrnovat i chemické složení korozní vrstvy.

\section{Popis vzorku}

131/2 - fragment dna silnostěnné sklářské pánve s bílým střepem pokrytým na vnitřní straně světle hnědou vrstvou skla

136/4 - fragment dna oxidačně vypáleného tyglíku se světle žlutou kompaktní vrstvičkou na dně 144 - fragment plechu z barevného kovu o rozměrech ca $45 \times 75 \mathrm{~mm}$ pokrytý nesouvislou vrstvou zeleně zbarvených korozních produktů

145/1 - fragment okraje oxidačně vypáleného tyglíku s nesouvislou načervenalou vrstvou na vnitřní stěně

146/1 - fragment dna poloredukčně vypáleného silnostěnného tyglíku s nesouvislou černou vrstvičkou na dně

146/2 - fragment okraje redukčně vypáleného tenkostěnného tyglíku s vrstvou nazelenalého skla, které přechází v černé sklovité krystaly

165 - velký fragment šedo-černé sklovité strusky

233/1 - fragment okraje poloredukčně vypálené tavicí misky s červeno-fialovou skvrnou na vnitřní stěně

263 - nehomogenní struska diskovitého tvaru na jedné straně se šedou souvislou vrstvou skla

280 - zlomek keramické kupole nebo roštu pícky s otvory o velikosti kolem $7 \mathrm{~mm}$

292/1 - zlomek tenkostěnné technické keramiky s vrstvou šedého, místy až černého skla na vnitřní stěně

295/1 - téměř kompletní tvar tenkostěnného oxidačně vypáleného tyglíku se zeleně zbarvenými drobnými závalky na vnitřních stěnách

$300 \mathrm{a}$ - nepravidelný fragment plechu z barevného kovu o rozměrech ca $15 \times 20 \mathrm{~mm}$ pokrytý nesouvislou vrstvou zeleně zbarvených korozních produktů

$300 \mathrm{~b}$ - nepravidelný fragment plechu z barevného kovu o rozměrech ca $40 \times 40 \mathrm{~mm}$ pokrytý nesouvislou vrstvou zeleně zbarvených korozních produktů

308/1 - zlomek stěny technické keramiky s šedou, místy černou nehomogenní vrstvou na vnitřní stěně

316 - menší oválný fragment šedo-černé sklovité strusky

$349 \mathrm{a}$ - fragment plechu z barevného kovu o rozměrech ca $10 \times 10 \mathrm{~mm}$ pokrytý nesouvislou vrstvou zeleně zbarvených korozních produktů 
$349 \mathrm{~b}$ - velmi nepravidelný fragment plechu z barevného kovu o rozměrech ca $40 \times 60 \mathrm{~mm}$ pokrytý nesouvislou vrstvou zeleně zbarvených korozních produktů

371/1 - dno silnostěnného oxidačně vypáleného tyglíku s nesouvislou červeno-fialovou vrstvou na dně

\begin{tabular}{|c|c|c|c|c|c|c|c|c|c|c|c|c|c|c|c|}
\hline $\begin{array}{l}\text { Wt } \\
(\%)\end{array}$ & $\mathrm{Si}$ & $\mathrm{Fe}$ & $\mathrm{Cu}$ & $\mathrm{Ag}$ & $\mathrm{Pb}$ & $\mathrm{Zn}$ & $\mathrm{Sb}$ & $\mathrm{Ni}$ & $\mathrm{Hg}$ & $\mathrm{Sn}$ & $\mathrm{Ti}$ & $\mathrm{Mn}$ & $\mathrm{Bi}$ & $\mathrm{Zr}$ & $\mathrm{P}$ \\
\hline $131 / 2$ & 12,88 & 0,11 & 49,67 & & 37,11 & & & & & & & 0,22 & & & \\
\hline $136 / 4$ & 95,92 & 0,58 & & 1,70 & 0,24 & & & & 1,56 & & & & & & \\
\hline 144 & 51,77 & 8,92 & 32,17 & & 3,58 & & & & & 3,13 & & 0,25 & & 0,17 & \\
\hline $145 / 1$ & 29,97 & 12,68 & 0,56 & & 51,66 & & & & 3,91 & & 0,96 & 0,26 & & & \\
\hline $146 / 1$ & 88,12 & 2,15 & 3,89 & 0,37 & 5,45 & & & 0,03 & & & & & & & \\
\hline $146 / 2$ & 15,38 & 14,60 & 1,20 & & 64,49 & 4,01 & & & & & & 0,32 & & & \\
\hline 165 & 50,96 & 13,81 & 3,84 & & 10,65 & 0,91 & & & 0,83 & & 1,43 & 17,32 & & & \\
\hline $233 / 1$ & 12,65 & 5,24 & 2,44 & & 75,79 & 0,48 & & & 1,52 & & 1,13 & & & & 0,76 \\
\hline 263 & 64,03 & 25,96 & 1,09 & & & 1,25 & & & & & 2,99 & 4,08 & & 0,60 & \\
\hline 280 & 12,08 & 3,38 & 1,29 & 2,22 & 81,03 & & & & & & & & & & \\
\hline $292 / 1$ & 64,72 & 21,48 & 5,07 & 3,69 & 1,18 & & & & 0,76 & & 1,90 & 0,95 & & 0,25 & \\
\hline $295 / 1$ & & 3,11 & 45,31 & 33,15 & 11,62 & & & & 6,83 & & & & & & \\
\hline $300 \mathrm{a}$ & 25,40 & 1,88 & 66,37 & & 3,60 & 0,35 & 0,24 & 0,15 & 1,10 & & & 0,05 & & & 0,85 \\
\hline $300 \mathrm{~b}$ & 25,56 & 0,83 & 69,11 & 0,26 & 0,62 & 0,89 & & 0,51 & & 2,05 & & & & & 0,26 \\
\hline $308 / 1$ & 52,77 & 21,32 & 4,83 & & 3,71 & & & & 0,77 & & & 16,38 & & 0,21 & \\
\hline 316 & 21,47 & 3,54 & 37,95 & & 10,58 & & 2,61 & 0,30 & & & 0,60 & 22,37 & 0,46 & 0,13 & \\
\hline $349 \mathrm{a}$ & 9,63 & 10,35 & 45,43 & & 10,49 & 3,37 & 19,72 & & 0,89 & & & 0,12 & & & \\
\hline $349 b$ & 14,86 & 0,92 & 78,62 & 0,89 & 0,51 & 0,82 & & 0,29 & 0,57 & 2,00 & & & & & 0,53 \\
\hline $371 / 1$ & 91,90 & 3,87 & 0,40 & 0,86 & 2,36 & 0,34 & & & & & 0,27 & & & & \\
\hline $146 / 1$ & 88,12 & 2,15 & 3,89 & 0,37 & 5,45 & & & 0,03 & & & & & & & \\
\hline
\end{tabular}

Tab. 1. Výsledky měření technické keramiky, strusek a plíšků nalezených na hradě Žampachu ručním XRF spektrometrem.

Tab. 1. Mit einem RFA-Handspektrometer erzielte Messergebnisse für die auf Burg Sandbach gemachten Funde an technischer Keramik, Schlacken und Metallplättchen.

\section{Popisy mincí a plíšku analyzovaných pomocí SEM-EDX}

M1 - Rakousko, vídeňský fenik se čtyřrázem, ražba po roce 1426 (sáček 321, vrstva 102 nebo 116)

M2 - Čechy, Vladislav Jagellonský (1471-1516), Kutná Hora, jednostranný bílý peníz (sáček 377, vrstva 104)

M3 - Čechy, Václav IV. (1376-1419), jednostranný peníz se lvem a čtyřrázem, ražba po roce 1384 až začátek 20. let 15. století (sáček 384, vrstva 122)

P1 - odebraný vzorek plechu měřený v předchozí tabulce pod číslem 349b 
Tento vzorek byl zalit do epoxidové pryskyřice a zhotoven klasický metalografický nábrus. Analýza P1/1 byla provedena na vlastním materiálu plechu a ukázala, že jde o měd'. Druhá analýza P1/2 se zaměřila na bíle se nabíjející částici v korozních produktech a pravděpodobně může souviset $\mathrm{s}$ postř́ibřním povrchu měděného plechu.

\begin{tabular}{|c|c|c|c|c|c|c|c|c|c|}
\hline $\mathrm{Wt}(\%)$ & $\mathrm{Ag}$ & $\mathrm{Cu}$ & $\mathrm{O}$ & $\mathrm{Si}$ & $\mathrm{Al}$ & $\mathrm{P}$ & $\mathrm{S}$ & $\mathrm{Cl}$ & $\mathrm{Ca}$ \\
\hline $\mathrm{M} 1 / 1^{*}$ & 41,21 & 20,03 & 24,15 & 6,97 & 0,70 & 2,64 & 0,70 & 0,74 & 2,86 \\
\hline $\mathrm{M} 1 / 2$ & 17,52 & 82,48 & & & & & & & \\
\hline $\mathrm{M} 1 / 3$ & 13,48 & 86,52 & & & & & & & \\
\hline $\mathrm{M} 2 / 1$ & 42,86 & 57,14 & & & & & & & \\
\hline $\mathrm{M} 2 / 2$ & 60,00 & 40,00 & & & & & & & \\
\hline $\mathrm{M} 3 / 1$ & 51,91 & 48,09 & & & & & & & \\
\hline $\mathrm{M} 3 / 2$ & 75,52 & 24,48 & & & & & & & \\
\hline $\mathrm{P} 1 / 1$ & 47,64 & 40,37 & & & 12,00 & & & & \\
\hline $\mathrm{P} 1 / 2$ & & 93,42 & 4,61 & & & & 1,37 & \\
\hline
\end{tabular}

Tab. 2. Chemické složení plíšku stanovené pomocí SEM-EDX (poznámka: M1/1* měřeny korozní produkty).

Tab. 2. Anhand REM-EDX ermittelte chemische Zusammensetzung der auf Burg Sandbach gemachten Metallplättchenfunde (Anmerkung: M1/1* Messung der Korrosionsprodukte).

\section{Diskuse}

Provedené analýzy naznačují, že soubor stř̌edověké technické keramiky a kovů z hradu Žampach s největší pravděpodobností souvisí s výrobou dobových mincovních falz. Středověké stříbrné mince byly padělány několika technikami. Nejrozšiřenější technikou falzátorských dílen bylo pokovení měděných stř́žko̊ pomocí amalgamu stříbra nebo cínu (Richtera-Zmrzlý 2014, 7-58). Hlavními indikátory padělání mincí na hradech jsou archeologické nálezy výrobního odpadu. Především jde o zbytky měděných plechů, ze kterých byly zhotovovány stř́žky. Dále také stř́ížky se stopami pokovení, které prozatím nebyly na hradě Žampach objeveny. Technice amalgamového postř́íbřování by mohly nasvědčovat analýzy plíšků nalezené na hradě Žampach, na jejichž povrchu jsme pomocí XRF spektrometru identifikovali stopy stř́ibra a rtuti. Další techniky fungovaly na principu př́ípravy tzv. bílého kovu (např. slitina $95 \% \mathrm{Sn}, 5 \% \mathrm{Cu}$ ). Současné chemické rozbory ukazují, že velmi často se objevuje žárové pocínování bez amalgamace, kdy $\mathrm{v}$ měděném kotli byly pokovovány měděné stř́žky v roztaveném cínu (Richtera-Zmrzlý 2014, 7-58). Pomocí metody XRF bylo dále prokázáno, že stopy pokovení je možné identifikovat, i pokud jsou plíšky překryty silnou vrstvou zeleně zbarvených korozních produktů. Je velkou výhodou metody XRF, že dokáže stopy postříbření identifikovat nedestruktivně. Pokud budeme vycházet $\mathrm{z}$ písemných pramenů, tak bychom se na hradě mohli setkat $\mathrm{s}$ falzy zhotovenými různými technikami, jak to dokládají zaznamenané výpovědi delikventů. Jan Krška při výslechu vypověděl: „Rozpouštěl jsem cejn a strojival sem jej jako střibro a odbejval sem toho za penize a strojíval to se mnou Korábek z Sedlčan a odbyl sem toho sedlákům asi sedm kusů za stř́bro, neb sem cejn rozpouštél slepičím sádlem a tudy bylo podobný $k$ střibru“ (Šebek 2010,287). Z této části výpovědi není zcela jasné, zda se týká zhotovování falz mincí nebo přípravy falešného kusového stříbra, navíc se tento záznam přímo netýká Žampachu, ale ukazuje na znalost falzátorských postupů i u spolupachatelů kováře Jana. Rovněž tato výpověd' může nasvědčovat znalosti prŕípravy bílého kovu, kterého šlo využít při zhotovování falz. Další techniku může dokládat jiná 
část výpovědi, kdy byl Krška dotazován, odkud brali stříbro. Pověděl, ,že jest tu střibra netřeba mnoho než když přepustili jochmtál [jáchymovský tolar] nebo dva a mezi to některej groš; s tím tehdy jsme jich nemálo nadělali“ (Šebek 2010, 292). Z této části zápisu lze usuzovat, že část falz musela být pokovena i stř́íbrem, a to velmi pravděpodobně amalgamační technikou.

Kromě kovových nálezů jsme analyzovali početný soubor technické keramiky se skelnými vrstvami a sklovité strusky nalezené při archeologickém výzkumu hradu (tab. 1). Vrstvy skla na technické keramice obsahují oxidy olova, zinku a mědi a vznikají při slévaní barevných a drahých kovů. Vrstva oxidů, která se tvoří na povrchu taveniny v tyglíku, za vysokých teplot reaguje se stěnami keramiky a vytváří barevné povlaky podobné glazurám. Zaznamenané prvkové složení skelných vrstev na technické keramice lze s největší pravděpodobností spojit s aktivitami penězokazecké dílny. Musíme ale připustit možnost, že se falzátorům podařilo získat použitou technickou keramiku z dílny prubíře. Technická keramika na hradě Žampach byla patrně použita bud' pro čištění stř́ibra nebo při různých těžko dešifrovatelných technikách nanášení stř́ibra nebo cínu na povrch měděných mincovních stř́ižků. V souboru technické keramiky se objevují velmi neobvyklé exempláře. Nacházíme zde např́iklad fragmenty sklářské pánve, chladicích sklářských nádob a patrně byly jako technická keramika použity i některé běžné kuchyňské tvary keramiky, které se nacházely na hradě (poháry). Tento předpoklad bude ještě muset být potvrzen důkladným studiem keramického materiálu.

K chemickým analýzám pomocí SEM-EDX byly předány i tři exempláře stříbrných mincí $\mathrm{z}$ hradu Žampach, které byly chemicky porovnány s vybraným plíškem z barevného kovu z téže lokality (tab. 2). Jak numismatický posudek, tak chemické analýzy pomocí SEM-EDX prokázaly, že mince jsou vyraženy ze stř́ibra a nejde o falza. Analýzy SEM-EDX doplnily informace o chemickém složení zkoumaného plíšku. Potvrdilo se, že jde o měděný plech, který na povrchu nese stopy stříbra. Musíme ale připustit možnost, že plechy nalezené na hradě jsou fragmenty měděných nádob, v nichž mohlo být prováděno pokovení střŕžků.

\section{Závěr}

Analytické metody i písemné prameny napomohly v př́ípadě hradu Žampach spojit vybrané archeologické nálezy s výrobou falz mincí. Některé otázky související s činností falzátorů na hradě zůstávají otevřené. Při archeologickém výzkumu hradu nebyly objeveny měděné stř́ǐky mincí, které by byly jednoznačným důkazem fungování penězokazecké dílny. Je možné, že se falza pouze nenacházela ve zkoumaných částech hradu, nebo kovář Jan, který byl usvědčen z penězokazectví, velmi důsledně zahladil stopy po své činnosti, než musel hrad opustit. Pokud by po jeho odchodu majitelé hradu objevili jakékoliv doklady padělání, rovnalo by se to jistému rozsudku smrti. Bohužel ani nalezené měděné plechy nelze jednoznačně vyhodnotit jako materiál pro stř́ǐžky nebo fragmenty z pokovovací nádoby. Překvapující je hojné množství technické keramiky na hradě. Pokud bychom vyloučili možnost, že kovář Jan získal již použité prubířské pomůcky, tak by soubor naznačoval, že se kromě obecně známých postupů pokoušel falza zhotovovat dle vlastních experimentů. Nalezený materiál i písemné prameny nasvědčují nesmírné vynalézavosti, zručnosti a téměř alchymistickým schopnostem kováře Jana. Hrad Žampach je z pohledu falzátorské činnosti na našem území zcela unikátní lokalitou. Z hradu prozatím neznáme jednoznačná falza mincí, ale spoustu indicií pokoutné činnosti osvětlují chemické analýzy ostatních archeologických nálezů, které spolu s historicky doloženou postavou kováře Jana vykreslují pozoruhodný kriminální příběh pozdního středověku na území východních Čech.

\section{Literatura}

ADAMEC, S., 2006: Písečná. Ves pod hradem Žampachem. Písečná.

BARTOŠ, M.-BRZÁK, P.-ŠEVCŮ, J., 2001: Prubířství a prubířská keramika - Das Probieren und die Probierkeramik, AH 26, 43-53. 
BELCREDI, L., 2012: Penězokazecká dílna na hradě Skály. In: Mezi raným a vrcholným středověkem, 583-598. Brno.

FRANCEK, J., 2011: Zločin a trest v Pardubicích 16.-18. století. Ústí nad Orlicí.

KOHOUTEK, J., 1995: Hrady jihovýchodní Moravy, 48-49. Zlín.

MUSIL, F., 2002: Osídlování Poorlicka v době předhusitské. Ústí nad Orlicí.

PLAČEK, M.-BÓNA, M., 2007: Encyklopedie slovenských hradů, 144-145. Praha.

PROFOUS, A.-SVOBODA, J., 1957: Místní jména v Čechách, jejich vznik, původní význam a změny IV. Praha.

RICHTERA, L.-ZMRZLÝ, M., 2013: Identifikace způsobů pokovení mincovních falz a možnost jejich citlivého ošetření. In: Ochrana mincí a medailí v muzejních sbírkách, 7-58. Brno.

SEDLÁČEK, A., 1883: Hrady, zámky a tvrze království Českého II, 119-131. Praha.

ŠEBEK, F., 2010: Dva př́iběhy z kriminálního podsvětí - padělatelé peněz na hradě Žampachu a přepadání Židů v roce 1542. In: Teatrum historiae 6, 285-308. Pardubice.

VENTURA, K., 2005: Analýza obsahu nádoby keramického tyglíku. Protokol o zkoušce a př́lohy z listopadu-prosince 2005. Katedra analytické chemie, fakulta chemicko-technologická, Univerzita Pardubice. Rkp. ulož. v archivu archeologického oddělení Východočeského muzea v Pardubicích.

ŽITAVSKÝ, P., 1976: Zbraslavská kronika. Praha.

\section{Zusammenfassung}

\section{Fundgegenstände einer mobilen Falschmünzerausstattung auf Burg Sandbach (Žampach, Bezirk Ústí nad Orlicí)}

Burg Sandbach liegt in Ostböhmen im Vorgebirge des Adlergebirges. Die erste indirekte Erwähnung der Burg ist in der Prädikatur eines Peters „de Sandbach“ von 1308 überliefert. Ungefähr Mitte des 14. Jahrhunderts wurde sie Eigentum der Herren von Sandbach von Pottenstein, die sie bis Mitte des 16. Jahrhunderts besaßen. In den Jahren 1513-1539 wurde die gesamte Grundherrschaft verpfändet, wobei sich mehrere Gläubiger abwechselten. Die Burg wurde in dieser Zeit nicht genutzt und verkam. Dies machte sich der Schmied Jan von Sandbach zunutze und ließ sich wahrscheinlich mit Wissen des Grundherrn mit seiner Frau und dem Gesinde auf der Burg nieder. Den sicheren und entlegenen Ort nutzte er dazu, eine Falschmünzerwerkstatt einzurichten. Diese wurde in der Zeit von ca. 1536 bis 1539 - mindestens jedoch zwischen 1537 und 1538 - von ihm und seinen Mitarbeitern betrieben. Dort fälschten sie die Görlitzer Schwarzmünze, ferner eine Wiener Münze, welche „die Gehörnte“ genannt wurde und bei der es sich offenbar um einen halben Kreuzer im Wert von drei Hellern handelte, sowie der österreichische Groschen bzw. Dreikreuzer. Die Prägestempel stellte sich der Schmied selbst her, was darauf hindeutet, dass er die Grundlagen des Goldschmiedehanderwerks bzw. der Schmuckmacherkunst beherrschte. Die Münzen prägte er mit seinen Mitarbeitern stoßweise, je nachdem, wie es ihnen gelang, das Material, d.h. das dazu notwendige Kupfer zu besorgen. Sie verwendeten vor allem Kupferkessel, die sie sich auch durch Diebstahl beschafften. Ihre Tätigkeit stellten sie im Zusammenhang mit der Auslösung der Burg ein, wozu es im Jahr 1539 kam. Die Informationen über die Falschmünzerwerkstatt und über die Ergreifung und Bestrafung ihrer Betreiber sind im ältesten erhaltenen Pardubitzer Achtbuch verzeichnet. Im Jahr 2013 erfolgte im Zusammenhang mit dem Aufbau eines Touristenrundgangs auch die Sicherung des eingestürzten Gewölbes eines Objektes im nordwestlichen Teil der Kernburg, bei dem es sich offensichtlich um das Eingangsobjekt handelte. Bei der Freilegung der Gewölbeoberseite entdeckte man in den Verfüllungen der Zerstörungsschichten Bruchstücke von technischer Keramik, Metallplättchen und Schlacke, was man mit der Tätigkeit der Falschmünzerwerkstatt in Verbindung bringen konnte. Leider konnte kein Falschgeld gefunden werden. Die Untersuchungen eines solch einzigartigen Materials erforderte die Anwendung zerstörungsfreier Prüfverfahren, sodass wir bei der technischen Keramik die Röntgenfluoreszenzanalyse (RFA) als das Grundprüfverfahren wählten. Die Metallplättchen wurden anhand eines Rasterelektronenmikroskops einer energiedispersiven Röntgenstrahlenanalyse unterzogen (REM-EDX). Durch die Analysen wurde nachgewiesen, dass die 
entdeckten Kupferbleche Spuren einer Silberplattierung aufweisen. Die zahlreich vertretenen Schmelztiegel und die übrige technische Keramik tragen auf der Oberfläche Silberamalgamspuren. Aufgrund der Ergebnisse der Analyseverfahren sowie nach Auswertung der schriftlichen Quellen nehmen wir an, dass auf Burg Sandbach Falschgeld in Form von versilberten und verzinnten Münzen hergestellt wurde.

Mgr. Miroslava Cejpová, Východočeské muzeum v Pardubicích, Zámek čp. 2, 53002 Pardubice, Česká republika, cejpova@vcm.cz

Mgr. Martin Hložek, Ph.D., Metodické centrum konzervace Technického muzea v Brně, Purkyňova 105, 61200 Brno, Česká republika, hlozek@technicalmuseum.cz 
